\title{
PENERAPAN METODE GIST (GENERATING INTERACTION SCHEMATA AND TEXT) DALAM PEMBELAJARAN MEMBACA PADA PENGAJARAN BAHASA INDONESIA DI PGSD UAD
}

\author{
Hanum Hanifa Sukma \\ PGSD, FKIP Universitas Ahmad Dahlan \\ hanum.sukma@gmail.com
}

\begin{abstract}
ABSTRAK
Penelitian ini dilatarbelakangi oleh kurangnya penguasaan metode membaca mahasiswa, sehingga mahasiswa hanya mampu membaca dengan satu gaya membaca untuk semua ragam wacana. Dampak dari kondisi ini adalah kemampuan membaca dan minat baca mahasiswa masih rendah. Penelitian ini bertujuan untuk mengetahui tingkat keefektifan metode GIST (Generating Interaction Schemata and Text) dalam pembelajaran membaca pemahaman. Penelitian ini menggunakan metode kuantitatif berupa metode eksperimen semu dengan desain penelitian pretest-posttestControl Group. Teori yang melandasi penelitian ini metode membaca GIST, dan membaca pemahaman. Data hasil penelitian berupa hasil tes mahasiswa kelas eksperimen dan kelas kontrol sebelum dan sesudah diberikan perlakuan yang berupa soal objektif sebanyak 30 soal untuk pretes dan 30 soal untuk postes. Melalui uji hipotesis hasil penelitian menunjukkan metode GIST (Generating Interaction Schemata and Text) efektif digunakan dalam pembelajaran membaca pemahaman.
\end{abstract}

Kata Kunci : Metode GIST (Generating Interaction Schemata and Text), kemampuan membaca pemahaman.

\section{PENDAHULUAN}

Membaca

merupakan

keterampilan penting dalam

mengembangkan kemampuan

berbahasa seorang mahasiswa, karena

proses belajar yang efektif antara lain

dilakukan melalui membaca.

Nurgiyantoro (2010: 368)

mengungkapkan kegiatan membaca

merupakan aktivitas mental memahami

apa yang dituturkan pihak lain melalui

sarana tulisan. Berbekal pada tingkat

pemahaman itu lah seseorang dapat

mendapatkan berbagai manfaat dari kegiatan membaca. Sayangnya pembelajaran membaca pemahaman masih menyisakan sejumlah problem tersendiri. Kurangnya penguasaan metode membaca adalah salah satu kendala yang membuat mahasiswa hanya mampu membaca dengan satu gaya membaca untuk semua ragam wacana. Dampak dari kondisi di atas adalah kemampuan membaca dan minat baca mahasiswa masih sangat rendah. Abidin (2012: 9) juga mengungkapkan rendahnya kemampuan efektif membaca para 
mahasiswa di sekolah, merupakan cermin utama kegagalan pembelajaran membaca yang dilakukan di sekolah. Tidak diterapkannya strategi atau metode membaca yang tepat ini menyebabkan rata-rata mahasiswa hanya mampu membaca secara monoton dan tidak pernah tahu bagaimana cara praktis dalam memahami bacaan. Bertemali dengan masalah di atas, maka diperlukan serangkaian upaya untuk mengatasi hal tersebut, salah satu upaya yang dapat dilakukan adalah dengan memperkenalkan berbagai strategi atau metode pembelajaran membaca yang mampu membentuk perilaku membaca sekaligus mampu mengembangkan kemampuan membaca pemahaman mahasiswa. Oleh karena itu penelitian terhadap kemampuan membaca pemahaman dengan metode tertententu perlu dilakukan. Salah satu metode membaca yang dirasa dapat digunakan dalam membaca pemahaman adalah metode GIST (Generating Interaction Schemata and Text). Penelitian ini bertujuan untuk menjawab hipotesis yang diajukan, yaitu Metode GIST (Generating Interaction Schemata and Text) tidak efektif atau efektif diterapkan pada pembelajaran membaca pemahaman
mahasiswaPGSD UAD. Adapun manfaat yang diharapkan, penelitian ini dapatmenjadi umpan balik bagi dosen dalam memilih metode pembelajaran yang lebih tepat, variatif dan dapat bermanfaat, mampu meningkatkan minat dan motivasi mahasiswadalam mengikuti pembelajaran yang pada akhirnya mampu meningkatkan kemampuannya dalam pembelajaran bahasa Indonesia, terutama pada pembelajaran membaca pemahaman.

\section{METODE PENELITIAN}

Penelitian ini menggunakan metode kuantitatif yaitu dengan data penelitian berupa angka-angka dan analisis satatistik. Metode kuantitatif yang digunakan dalam penelitian ini berupa metode eksperimen semu dengan desain penelitian pretestposttestControl Group. Desain penelitian tersebut menggunakan dua kelompok objek penelitian, yaitu kelompok eksperimen dan kelompok kontrol (Sugiono 2012: 76). Teknik memilih objek/sampel dilakukan secara simple random sampling, yang dapat dilakukan secara tradisional yaitu dengan sistem undian atau kocokan (Sukardi, 2011: 58). Prosedur yang digunakan yakni dengan melakuan tes 
awal di kelas eksperiemn dan kelas kontrol untuk menguji kemampuan mahasiswa dalam membaca pemahaman. Kedua dengan memberikan bimbingan dan arahan membaca pemahamn di kelas eksperimen dengan metode GIST di kelas kontrol. Ketiga dilakukan tes akhir pada kedua kelas tersebut guna mengetahui kemampuan membaca pemahaman mahasiswa setelah diberi perlakuan dengan menggunakan metode GIST.Populasi yang digunakan dalam penelitian ini adalah seluruh mahasiswasemester 2 PGSD UAD.

\section{HASIL PENELITIAN}

Hasil penelitian ini merujuk pada data yang telah dikumpulkan dari seluruh sampel yang telah diolah secara sistematis, objektif dan dengan cara-cara penghitungan yang ilmiah. Berdasarkan hasil pretes dan postes di kedua kelas, yaitu kelas eksperimen (2C) dan kelas kontrol (2F), terlihat perbedaan nilai rata-rata yang signifikan. Peningkatan nilai rata-rata postes pada kelas eksperimen lebih tinggi dibandingkan dengan kelas kontrol. Nilai terendah yang diperoleh kelas eksperimen (menggunakan metode GIST) pada saat pretes adalah 53, nilai tertinggi 90, dan diperoleh nilai rata-rata sebesar 73.45. Hasil pretes pada kelas eksperimen terdapat 19 mahasiswayang berhasil dan 14 mahasiswa yang gagal. Sementara itu hasil postes didapat nilai terendah 63 , nilai tertinggi 93, dan diperoleh nilai rata-rata sebesar 83.73. Dari hasil postes diketahui sebanyak 32 mahasiswa berhasil dan seorang mahasiswa gagal. Hal ini disesuaikan dengan KKM yang ditetapkan untuk mata kuliah bahasaIndonesia yaitu 70.Sementara itu nilai terendah yang diperoleh oleh kelas kontrol (menggunakan metode langsung/ceramah) pada saat pretes adalah 53, nilai tertinggi 86 , dan diperoleh nilai rata-rata sebesar 75,87 . Berdasarkan hasil pretes pada kelas control tersebut terdapat 24 mahasiswa yang berhasil dan 9 mahasiswa yang gagal. Sementara itu dari hasil postes didapat nilai terendah 63, nilai tertinggi 90, dan diperoleh nilai rata-rata sebesar 79,60. Dari hasil postes diketahui sebanyak 26 mahasiswa berhasil dan 7 mahasiswagagal. Hal itu disesuaikan dengan KKM yang ditetapkan untuk mata kuliah bahasa Indonesia yaitu 70 . Perbedaan yang signifikan nilai ratarata pretes dan postes antara kelas eksperimen dan kelas kontrol dapat terlihat dari tabel berikut. 

Tabel 1

Pretest dan postest

\section{No Kelas Eksperimen Kontrol}

\begin{tabular}{|l|c|c|c|c|}
\hline \multirow{2}{*}{$\mathrm{N}=45$} & \multicolumn{2}{|c|}{ Kelas Eksperimen } & \multicolumn{2}{c|}{ Kelas Kontrol } \\
\cline { 2 - 5 } & Pretest & Posttest & Pretest & Posttest \\
\hline Minimum & 35,00 & 67,00 & 68,82 & 32,00 \\
\hline Maximum & 75,00 & 93,00 & 88,00 & 89,00 \\
\hline Mean & 66,11 & 81,00 & 68,82 & 74,51 \\
\hline Std. Deviation & 6,84 & 5,92 & 7,20 & 8,80 \\
\hline
\end{tabular}

Tabel 1 menunjukkan terjadi peningkatan nilai dari sebelum dan pemahaman yang dilakukan setelah diberikan perlakuan. Dengan mahasiswa masih terbilang kurang dan demikian dapat dikatakan bahwa jauh dari yang peneliti harapkan. terdapat peningkatan hasil belajar mahasiswa, serta dapat disimpulkan bahwa metode GIST Pembelajaran membaca pemahaman khususnya pembelajaran membaca untuk menemukan gagasan utama (GeneratingInteraction Schemata and Text) efektif diterapkan pada merupakan pembelajaran yang masih kurang diminati oleh mahasiswa. Hal pembelajaran membaca pemahaman di semester 2 PGSD UAD tahun 2015/2016. Hasil penelitian ini menjawab dan membuktikan hipotesis (H1) yaitu, metode GIST (Generating Interaction Schemataand Text) efektif diterapkan pada pembelajaran membaca pemahaman.

\section{PEMBAHASAN}

Profil Membaca Pemahaman Mahasiswa tersebut terlihat dari hasil mahasiswa dalam pembelajaran membaca dan dari hasil pengamatan terhadap proses pembelajaran di kelas.Selain itu melakukan wawancara dengan beberapa mahasiswa, dari hasil wawaancara terlihat bahwa dari empat keterampilan aspek berbahasa, mahasiswa lebih menyukai keterampilan menyimak dan menulis dari pada keterampilan membaca. Menurut para mahasiswa pembelajaran membaca merupakan pembelajaran 
yang monoton dan membosankan, kalaupun mereka membaca, mereka lebih senang membaca bacaan seperti novel dan komik. Kesulitan yang sering dihadapi mahasiswa pada pembelajaran ini adalah sulitnya menentukan intisari bacaan. Selain itu mahasiswa juga cenderung sulit memahami isi bacaan karena jenis bacaan yang digunakan terlalu membosankan, tidak sesuai dengan karakteristik mahasiswa, sehingga tidak menimbulkan ketertarikan pada mahasiswauntuk membacanya. Metode pembelajaran yang digunakan guru pun masih terlalu kaku. Pembelajaran membaca untuk menemukan gagasan utama ini diajarkan tanpa memberikan meteri yang cukup, metode/teknik yang sesuai dan media yang menunjang. Pembelajaran ini dilakukan seperti pada pembelajran lainnya, guru hanya menjelaskan materi yang ada di buku paket dan setelahnya memberikan tugas yang sudah tersedia di buku paket pula. Setelah diterapkan pembelajaran membaca pemahaman dengan metode GIST, mahasiswa mengalami peningkatan dalam kemampuan membaca pemahaman untuk menemukan gagasan utama. Hal ini terlihat jelas dari perbedaan nilai yang signifikan sebelum dilakukan pembelajaran dengan metode GIST berorientasi pengalaman dieroleh nilai rata-rata sebesar 73.45 dan setelah dilakukan pemeblajran dengan metode GIST berorientasi pengalaman diperoleh nilai rata-rata sebesar 83,73.

\section{Rancangan Pembelajaran Membaca} Pemahaman

Sebelum melakukan penelitian, peneliti terlebih dahulu melakuakan tes awal (pretes) untuk mengetahui kemampuan awal mahasiswa dalam membaca pemahamna untuk menemukan gagasan utama, setelah itu barulah peneliti merancang pembelajaran. Rancangan pembelajaran dalam penelitian ini meliputi merumuskan tujuan pembelajaran, menentukan sumber, media, dan bahan pembelajaran, merumuskan alat evaluasi dan menentukan alokasi waktu pembelajaran.

a. Merumuskan tujuan pembelajran Tujuan pembelajaran yang dirumuskan pada penelitian ini merujuk pada RPS dan RPM mata kuliah bahasa Indonesia di PGSD UAD.

b. Sumber dan media pembelajaran Sumber yang digunakan guna menunjang pembelajaran dalam 
penelitian ini adalah buku materi pembelajaran bahasa Indonesia kelas dan beberapa buku penunjang lainnya. Sedangkan untuk media, peneliti menggunakan beberapa wacana yang bersumberdari media cetak maupun elektronik

c. Merumuskan alat evaluasi .

Alat evaluasi yang disusun oleh peneliti berupa tes tertulis dengan bentuk soal objektif (pilihan ganda) berjumlah 60 soal dengan kriteria nilai ideal 100. Selain itu tes ini juga dilangkapi enam buah wacana, yang dibagi menjadi tiga wacana beserta 30 soal untuk pretes dan tiga wacana beserta 30 soal untuk postes. Masingmasing wacana disertai 10 butir soal. Wacana yang digunakan sudah disesuaikan dan dihitung menggunakan Grafik Fry.

a. Alokasi waktu

Alokasi waktu pembelajaran yang ditetapkan dalam penelitian ini selama tiga pertemuan atau $6 \times 40$ menit (240 menit).

Pembahasan Proses Pembelajaran Membaca Pemahaman dengan Metode GIST

Kegiatan pembelajaran dalam penelitian ini selain memberikan materi mengenai membaca pemahaman untuk menemukan gagasan utama, juga melakukan kegitan-kegiatan simulasi yang berkaitan dengan isi ketiga wacana yang akan diberikan pada saat postes. Kegiatan simulasi ini bertujuan untuk menimbulkan atau membangun pengalaman mahasiswa sesuai dengan isi wacana, hal ini dilakukan guna mempermudah mahasiswa dalam memahami isi wacana. Selain itu, peneliti juga menggunakan teknik observasi untuk menilai proses pembelajaran. Observasi dilakukan untuk menilai kegiatan pembelajaran menggunakan metode GIST. Penilain menggunakan keterangan "terlaksana sempurna" untuk menilai kegiatan pembelajaran yang sudah direncanakan dan terlaksana dengan sempurna tanpa hambatan apapun, keterangan "terlaksana dengan hambatan" untuk kegiatan pembelajaran yang direncanakan dan terlaksana namun dalam pelaksanaanya mengalami beberapa hambatan, keterangan "tidak terlaksana" untuk kegiatan pembelajaran yang direncanakan namun tidak terlaksana sama sekali. Aspek-aspek yang diobservasi dalam penelitian ini meliputi, kegiatan membuka pembelajaran, kemampuan menjelaskan materi dan metode, kegiatan membangun pengalaman 
mahasiswa, kegiatan memeberikan evaluasi, memberikan umpan balik dalam bentuk korektif, dan kegiatan penutup pembelajaran. Selama pembelajaran mahasiswa telah memperoleh pengalaman yang sesuai dengan isi wacana, sehingga ketika mahasiswa melakukan tes akhir (postes) nanti mahasiswa telah memiliki ingatan yang kuat dari pengalaman yang telah diperolehnya. Hal ini akan mempermudah mahasiswa dalam memahami isi wacana.

\section{Tingkat Keefektifan Metode GIST dalam Pembelajaran Membaca Pemahaman}

Penelitian ini bertujuan untuk melihat tingkat efektivitas metode GIST (Generating Interaction Schemata and Text) padapembelajaran membaca pemahaman, khususnya bagi mahasiswasemester 2 PGSD UAD tahun 2015/2016. Setelah melakukan penghitungan persyaratan analisis data diketahui data sampel penelitian berdistribusi normal dan homogen dengan taraf kepercayaan 99\%. Normalitas data untuk menentukan kelanjutan penghitungan dan jenis penghitungan statistik apa yang akan dipakai (Subana, 2000:123). Sementara itu homogenitas data artinya adanya keseragaman varians sampelsampel yang diambil dari populasi yang sama. Setelah melakukan penghitungan normalitas dan homogenitas diketahui data penelitian ini berdistribusi normal dan homogen, selanjutnya adalah melakukan penghitungan uji hipotesis (t-test). Pada taraf signifikansi Pada taraf signifikansi $(\alpha)=0,20$. Maka $t$ tabel $=$ $(1-0,20)(64)=51,2$. Dengan hasil $d k=$ 64, maka berdasarkan ttabel didapat nilai 1,296. Hasil penelitian ini menunjukkan thitung $=1,485$ dan ttabel $=1,296$, sehingga thitung $(1,485)$ $>$ ttabel $(1,296)$. Dengan taraf/tingkat keefektifan sebesar $(\alpha)=0,20(70 \%)$, maka hipotesis HI diterima, yaitu metode GIST (Generating InteractionSchemata and Text) berorientasi pengalaman efektif diterapkan pada pembelajaran membaca pemahaman.

\section{PENUTUP}

Berdasarkan hasil penelitian dan pembahasan yang telah dipaparkan sebelumnya, ada beberapa hal yang dapat disimpulkan. Penggunaan metode GIST yang berorientasi pengalaman dapat membantu mahasiswa dalam memahami isi bacaan. Perlakuan bimbingan selama 
tiga kali perlakuan mempu menuai hasil yang memuaskan. Hal tersebut terlihat dari perbedaan nilai rata-rata yang signifikan antara kelas eksperimen dan kontrol sebelum dan setelah perlakuan. Pengalaman adalah kegiatan yang langsung dialami dan akan mudah diingat sehingga akan mempermudah pemahaman pula. Berdasarkan hasil penelitian metode GIST (Generating Interaction Schemataand Text) efektif digunakan dalam pembelajaran membaca pemahaman. Bagi guru yang ingin menggunakan metode GIST (Generating Interaction Schemata and Text) yang berorientasi pengalaman, harus lebih kreatif lagi khususnya dalam menciptakan pengalaman bagi mahasiswa. Penggunaanmetode membaca yang tepat akan mempermudah mahasiswa dalam memahami isi bacaan,selain itu pengalaman juga merupakan salah satu penunjang pemahaman dan ingatan yang baik. Metode GIST (Generating Interaction Schemata and Text) yang berorientasi pengalaman dapat dijadikan salah satu alternatif bagi mahasiswa dalam melakukan aktivitas membaca yang bertujuan untuk memahami isi bacaan dan menemukan gagasan utama. Bagi para peneliti lainnya yang ingin menggunakan metode GIST (Generating Interaction Schemata and Text), penelitian ini dapat dijadikan acuan namun, peneliti juga harus lebih kreatif dan mendalam lagi dalam mengemas pelaksanaan penelitiannya tersebut. Metode ini juga dapat diterapkan dalam pembelajaran membaca lainnya.

\section{DAFTAR PUSTAKA}

Abidin, Yunus. 2012. Pembelajaran Membaca Berbasis Pendidikan Karakter. Bandung: Refika Aditama.

Nurgiyantoro, Burhan. 2010. Penilaian Pembelajaran Bahasa BerbasisKompetensi.

Yogyakarta: BPFE.

Subana, dkk. 2000. Statistik Pendidikan. Bandung: Pustaka Setia.

Sugiyono. 2012. Metode Penelitian Pendidikan (Pendekatan Kuantitatif, Kualitatif,dan $R \&$ D). Bandung: Alfabeta. 